\title{
Teenager with a history of acute myeloid leukaemia with an isolated brain lesion
}

\author{
Donna Johnston, ${ }^{1}$ Joerg Krueger, ${ }^{2}$ Lesleigh Abbott ${ }^{1}$
}

'Division of Hematology/ Oncology, Children's Hospital of Eastern Ontario, Ottawa, Ontario, Canada ${ }^{2}$ Division of Hematology/ Oncology, Hospital for Sick Children, Toronto, Ontario, Canada

\section{Correspondence to} Dr Donna Johnston: djohnston@cheo.on.ca

Accepted 30 April 2020
A Check for updates

(c) BMJ Publishing Group Limited 2020. No commercial re-use. See rights and permissions. Published by BMJ.

\begin{tabular}{l}
\hline To cite: Johnston D, \\
Krueger J, Abbott L. BMJ \\
Case Rep 2020;13:e234857. \\
doi:10.1136/bcr-2020- \\
234857 \\
\hline
\end{tabular}

\section{DESCRIPTION}

A 12-year-old girl was diagnosed with acute myeloid leukaemia (AML) with cytogenetics showing inv(14) (q11.2q32). Cerebrospinal fluid (CSF) was negative for leukaemia. She was treated based on Children's Oncology Group protocol AAML1031 with an Medical Research Council (MRC)-based backbone of therapy. Following one chemotherapy cycle, remission was obtained and minimal residual disease (MRD) testing was negative. She completed five cycles of chemotherapy and her CSF was negative throughout therapy. She underwent imaging of her head as part of the workup for prolonged febrile neutropenia and this was normal. She was well for 7 months (13 months from original diagnosis) when she developed new onset ataxia and headaches. She underwent MRI (figures 1-3), which demonstrated a posterior fossa mass involving the vermis and causing secondary tonsillar herniation. The lesion enhanced with contrast and had surrounding oedema. The differential at this time was felt to be relapse of her AML, development of a new brain tumour or less likely an infection.

As relapse of AML was the most likely diagnosis, a bone marrow was done which was normal. MRD testing was negative and lumbar puncture was not able to be safely done because of cerebellar tonsillar descent. Because the diagnosis of relapse could not be confirmed, she underwent resection of the mass, which showed a granulocytic sarcoma with the same flow cytometry and cytogenetic abnormality as her original AML. This is similar to reports in the literature of a cerebellar myeloid sarcoma relapse of AML in a paediatric patient. ${ }^{1}$ Her neurological symptoms resolved post surgery. Repeat marrow 10

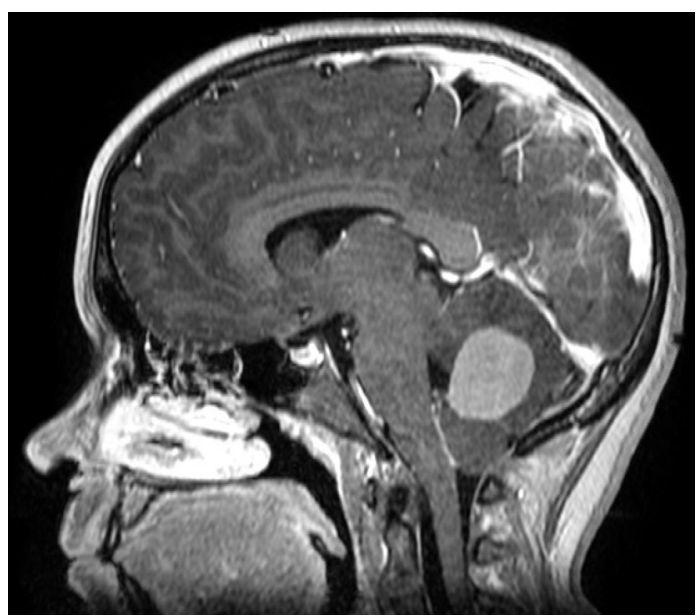

Figure 1 Sagittal MRI image showing lesion in cerebellum with surrounding oedema.

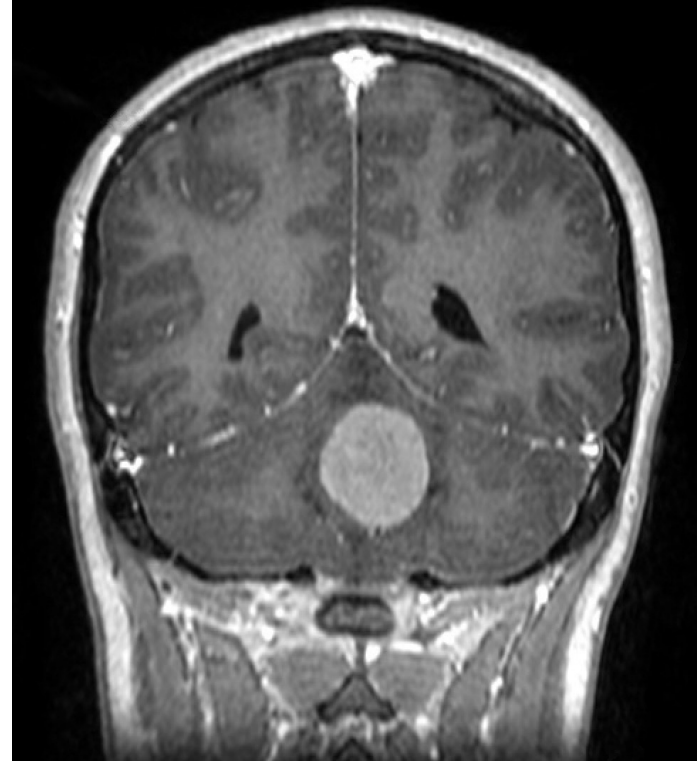

Figure 2 Coronal image.

days after the first marrow, and lumbar puncture, showed negative CSF but the marrow was positive for disease by MRD testing. She was treated with radiation therapy (1800 cGy in 10 fractions to the whole brain with a $540 \mathrm{cGy}$ boost to the tumour bed), and chemotherapy with fludarabine, cytarabine and granulocyte colony-stimulating factor followed by an unrelated donor stem cell transplant conditioned with fludarabine, busulfan and thiotepa. She remains in remission, 10 months since her relapse.

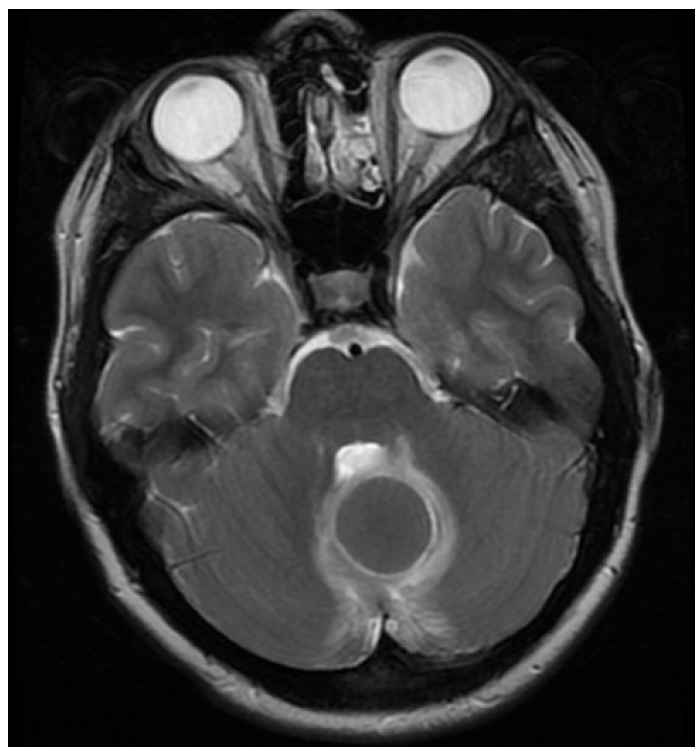

Figure 3 Axial image. 


\section{Learning points}

There should be a very low threshold to perform central nervous system imaging for worrisome or new neurological symptoms in patients with a history of acute leukaemia.

- An isolated cerebellar lesion is an unusual presentation of acute myeloid leukaemia relapse, thus confirmation of the diagnosis with tissue is necessary before initiating therapy.
Contributors DJ, JK and LA contributed to collecting the data, writing the case report and reviewing of the final version of the report.

Funding The authors have not declared a specific grant for this research from any funding agency in the public, commercial or not-for-profit sectors.

Competing interests None declared.

Patient consent for publication Parental/guardian consent obtained.

Provenance and peer review Not commissioned; externally peer reviewed. REFERENCE

1 Psiachou-Leonard E, Paterakis G, Stefanaki K, et al. Cerebellar granulocytic sarcoma in an infant with CD56+ acute monoblastic leukemia. Leuk Res 2001;25:1019-21.

Copyright 2020 BMJ Publishing Group. All rights reserved. For permission to reuse any of this content visit https://www.bmj.com/company/products-services/rights-and-licensing/permissions/

BMJ Case Report Fellows may re-use this article for personal use and teaching without any further permission.

Become a Fellow of BMJ Case Reports today and you can:

- Submit as many cases as you like

- Enjoy fast sympathetic peer review and rapid publication of accepted articles

- Access all the published articles

- Re-use any of the published material for personal use and teaching without further permission

\section{Customer Service}

If you have any further queries about your subscription, please contact our customer services team on +44 (0) 2071111105 or via email at support@bmj.com.

Visit casereports.bmj.com for more articles like this and to become a Fellow 